\title{
Biochemical and molecular characterization of N66 from the shell of Pinctada mazatlanica
}

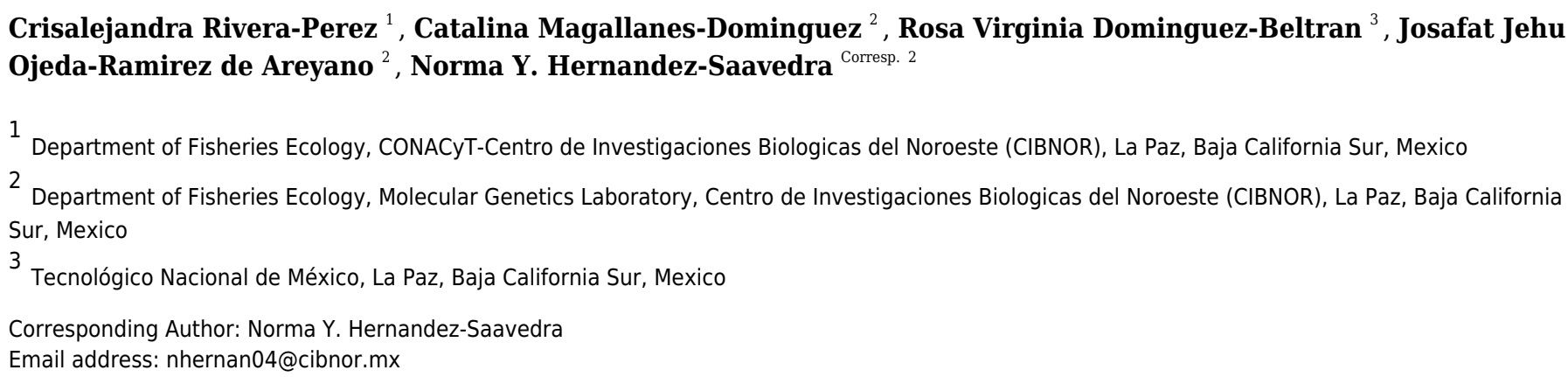

Mollusks shell mineralization is a tightly controlled process by shell matrix proteins. However, the study of shell matrix proteins has been limited to a few model species. In this study, the N66 mRNA of the pearl oyster Pinctada mazatlanica was cloned and functionally characterized. The full sequence of N66 mRNA consist of 1766 base pairs, and encodes one N66 protein. A sequence analysis revealed that N66 contained two carbonic anhydrase domains, a NG domain and several glycosylation sites. The sequence showed similarity to the carbonic anhydrase VII but also with its homolog protein nacrein. The native N66 protein was isolated from the shell and identified by mass spectrometry, the peptides sequenced matched to the nucleotide sequence obtained. Native N66 is a glycoprotein with a molecular mass of 60-66 kDa which displays carbonic anhydrase activity and calcium carbonate precipitation ability in presence of different salts. Also, a recombinant form of N66 was produced in Escherichia coli, and functionally characterized. The recombinant $\mathrm{N} 66$ displayed higher carbonic anhydrase activity and crystallization capability than the native N66, suggesting that the lack of posttranslational modifications in the recombinant $\mathrm{N} 66$ might modulate its activity. 


\section{Biochemical and molecular characterization of N66 from the shell of Pinctada}

2 mazatlanica

3

4 Crisalejandra Rivera-Perez ${ }^{1}$, Catalina Magallanes-Dominguez ${ }^{2}$, Rosa Virginia Dominguez-

5 Beltran $^{3}$, Josafat Jehu Ojeda-Ramirez de Areyano ${ }^{2}$, Norma Y. Hernandez-Saavedra ${ }^{2 *}$

$6{ }^{1}$ Department of Fisheries Ecology, CONACYT-Centro de Investigaciones Biológicas del

7 Noroeste (CIBNOR), La Paz, Baja California Sur, México.

$8{ }^{2}$ Department of Fisheries Ecology, Molecular Genetics Laboratory, Centro de Investigaciones

9 Biológicas del Noroeste (CIBNOR), La Paz, 23096, Baja California Sur, México.

$10{ }^{3}$ Tecnológico Nacional de México, La Paz, 23080, Baja California Sur, México.

11 *Corresponding author: nhernan04@cibnor.mx

12 


\section{Abstract}

22 Mollusks shell mineralization is a tightly controlled process by shell matrix proteins. However,

23 the study of shell matrix proteins has been limited to a few model species. In this study, the N66

24 mRNA of the pearl oyster Pinctada mazatlanica was cloned and functionally characterized. The

25 full sequence of N66 mRNA consist of 1766 base pairs, and encodes one N66 protein. A

26 sequence analysis revealed that N66 contained two carbonic anhydrase domains, a NG domain

27 and several glycosylation sites. The sequence showed similarity to the carbonic anhydrase VII

28 but also with its homolog protein nacrein. The native N66 protein was isolated from the shell and

29 identified by mass spectrometry, the peptides sequenced matched to the nucleotide sequence obtained. Native N66 is a glycoprotein with a molecular mass of 60-66 kDa which displays carbonic anhydrase activity and calcium carbonate precipitation ability in presence of different salts. Also, a recombinant form of N66 was produced in Escherichia coli, and functionally characterized. The recombinant N66 displayed higher carbonic anhydrase activity and crystallization capability than the native N66, suggesting that the lack of posttranslational modifications in the recombinant N66 might modulate its activity. 
42

43

44

45

46

47

48

49

50

51

52

53

54

55

56

57

58

59

60

61

62

63

64

65

\section{Introduction}

Mollusks are known for their ability to build shells having a diversity of sizes, forms and structures. The mollusk shells are mainly composed of calcium carbonate (aragonite, calcite, and nacre), and synthesized by shell matrix proteins (SMPs) (Addadi et al., 2006). SMPs are

synthesized in the mantle and secreted to the extrapalleal space, located between the shell and the mantle, where interact with bicarbonate ions $\left(\mathrm{HCO}^{3-}\right)$, calcium $\left(\mathrm{Ca}^{2+}\right)$, polysaccharides and metal traces $\left(\mathrm{Mg}^{2+}\right)$ (Xie et al., 2016; Liu et al., 2011), leading to aragonite microstructures (nacre, crossed-lamellar and complex crossed-lamellar) and calcite microstructures (prismatic and foliated) (Zhang \& Zhang, 2006). The nacre layer of the shell consists of organized crystal aragonite tablets forming a brick and mortar construction (Mutvei, 1980) which displays outstanding biomechanical properties, such as toughness, elasticity, light weight or softness (Checa, Macias-Sanchez \& Ramirez-Rico, 2016).

Although, aragonite assembly process is not well understood, several SMPs involved in aragonite crystal growth have been identified in several marine mollusks (Zhang \& Zhang, 2006) through transcriptomic and proteomic analysis (Miyamoto et al., 2013; Mann, EdsingerGonzalez \& Mann, 2012). Nacrein and N66 proteins play a significant role in the biomineralization process, they are soluble enzymes involved in the calcium carbonate crystallization and participates in the formation of the nacreous layer (Miyamoto et al., 1996). Nacrein and N66 are metalloenzymes with one Gly-Xaa-Asn repeat domain (Xaa: Asp, Asn, or Glu, NG-repeat domain) at the C-terminal end (Song et al., 2014; Mann, Edsinger-Gonzalez \& Mann, 2012; Norizuki \& Samata, 2008; Kono, Hayashi \& Samata, 2000; Miyamoto, Yano \& Miyashita, 2003; Miyamoto et al., 1996) and two carbonic anhydrase (CA) domains which belong to the CA superfamily. All nacrein and N66 proteins described in mollusks belong to the 
66

67

68

$\alpha$-CA family, class II and VII, respectively (Mann, Edsinger-Gonzalez \& Mann, 2012; Leggat et al., 2005; Kono, Hiyashi \& Samata, 2000; Miyamoto et al., 1996). These proteins are known to contain a metal ion $\left(\mathrm{Zn}^{2+}\right)$ coordinated by three His residues at the active site (Ozensoy, Capasso \& Supuran, 2016) and catalyze the reversible hydration of carbon dioxide to bicarbonate (Miyamoto et al., 1996).

These proteins are conserved in bivalves and gastropods and have a molecular weight ranging from $50 \mathrm{kDa}$ to $66 \mathrm{kDa}$ (Song et al., 2014; Mann, Edsinger-Gonzalez \& Mann, 2012; Leggat et al., 2005; Miyamoto, Yano, Miyashita, 2003; Kono, Hayashi \& Samata, 2000; Miyamoto et al., 1996). Previous studies have recognized that nacrein and N66 are glycoproteins (Leggat et al., 2005; Kono, Hayashi \& Samata, 2000), where nacrein possess N-glycan containing sulfite and sialic acid at its terminus (Takakura et al., 2008), furthermore, they both have calcium binding ability (Miyamoto et al., 1996). Despite their similar biochemical properties, N66 has almost twice length of NG repeat domain than nacrein (Miyamoto, Yano \& Miyashita, 2003; Kono, Hayashi \& Samata, 2000; Miyamoto et al., 1996). This domain has been proved to function as negative regulator in shell formation in nacrein (Miyamoto, Miyoshi \& Kohno, 2005), and also as a positive regulator, both as a $\mathrm{Ca}^{2+}$ concentrator and an enzyme required for production of carbonate ions (Norizuki \& Samata, 2008). The longer repeat NG domain have been related to stronger reaction of protein with $\mathrm{Ca}^{2+}$ molecules, matrix components and crystals, resulting in an improved calcification capability (Samata et al., 1999). The nacrein gene has been described in the bivalve Pinctada maxima (Kono, Hayashi \& Samata, 2000) and the gastropod Turbo marmoratus (Miyamoto, Yano \& Miyashita, 2003), while N66 gene has been only described in P. maxima (Kono, Hayashi \& Samata, 2000). Differential expression of SMP mRNAs in the mantle of mollusks has been related to their 
89

90

91

92

93

94

95

96

97

98

crystal layer formation. Nacrein mRNA is highly expressed in the mantle edge and pallial (Miyamoto, Miyoshi \& Kohno, 2005; Miyamoto et al., 1996), while N66 mRNA is expressed in the dorsal region of the mantle and the mantle edge (Kono, Hayashi \& Samata, 2000), the former has been associated for the nacreous layer function and the latter for the prismatic layer formation (Sudo et al., 1997).

In order to gain insights into the biomineralization processes in mollusk and to increase the knowledge of the nacre formation, a comprehensive study of the proteins involved in nacre deposition is required. Pearl oyster, Pinctada mazatlanica is a good model species to study biomineralization, since includes two layers, an inner nacreous layer, and an outer prismatic calcite layer. In this study, a N66 from the shell was isolated and its coding sequence was obtained from the mantle of the pearl oyster $P$. mazatlanica and overexpressed on a prokaryotic system, the resulting native and recombinant proteins were functionally characterized.

\section{Material \& Methods}

Biological material. Three adult female organisms were provided by Perlas del Cortez S. de R.L. MI. located at Bahia de La Paz B.C.S. Organisms were transported to the Molecular Genetics Laboratory at CIBNOR, and mantle tissue was dissected and stored at $-80{ }^{\circ} \mathrm{C}$ until used.

\section{Molecular characterization of N66 from mantle tissue}

Total RNA extraction and RNA reverse transcription. Total RNA was extracted with TRIzol® (Invitrogen, U.S.A.) according to the manufacturer's instructions. Samples were homogenized using a glass pestle; then, two consecutive extractions of each sample were made. RNA purity and concentration were determined by spectrophotometry using a NanoDrop ND- 
1122000 (Thermo Scientific, U.S.A.) at 260/280 and 260/230 nm absorbance ratios (range, 1.9 -

113 2.0). The RNA integrity was assessed on $1 \%(\mathrm{w} / \mathrm{v})$ agarose-synergel gel. To ensure complete

114 DNA absence, a direct PCR was performed using $1 \mu \mathrm{L}(50 \mathrm{ng} / \mu \mathrm{L})$ of each RNA preparation

115 with $28 \mathrm{~S}$ ribosomal specific primer as a non-amplified control. After that, $1 \mu \mathrm{g}$ of total RNA was

116 used from each verified RNA sample for cDNA synthesis using the cloned AMV First-Strand

117 cDNA Synthesis Reaction (Invitrogen, U.S.A.) and oligo-dT primer, afterwards cDNAs were

118 stored at $-80{ }^{\circ} \mathrm{C}$ until use. Control reactions were performed without template or non-reverse

119 transcribed RNA to determine the presence of DNA.

120

121

Amplification of coding sequence of N66 from mantle. A search for sequences

122 encoding N66 from mollusks available at GenBank yielded three homologous sequences, N66

123 Pinctada maxima (GenBank: AB032613), N44 P. maxima (GenBank: FJ913472) and SP-S

124 Mizuhopecten yessoensis (GenBank: AB185328). Based on these sequences, specific primers

125 were designed to amplify the coding sequence of N66 (Table 1). PCR amplification of cDNA

126 fragments encoding N66 was done in a final volume of $12.5 \mu \mathrm{L}$ containing 10 pmol of each

127 forward and reverse primer, $50 \mathrm{ng}$ cDNA, $10 \mathrm{nmol}$ dNTPs mixture, $1.25 \mu \mathrm{L}$ 10X Taq Buffer, and

$1281 \mathrm{U}$ Taq DNA polymerase (11615010A, Invitrogen). PCR amplification were carried out for 5

$129 \min$ at $94{ }^{\circ} \mathrm{C}$, followed by 5 cycles consisting $1 \mathrm{~min}$ at $94{ }^{\circ} \mathrm{C}, 1 \mathrm{~min}$ at $40{ }^{\circ} \mathrm{C}$, and 2 min at $72{ }^{\circ} \mathrm{C}$,

130 followed of 35 cycles consisting $1 \mathrm{~min}$ at $94{ }^{\circ} \mathrm{C}, 1 \mathrm{~min}$ at $50^{\circ} \mathrm{C}$, and $2 \mathrm{~min}$ at $72{ }^{\circ} \mathrm{C}$. In the last

131 cycle, the extension step at $72{ }^{\circ} \mathrm{C}$ lasted $10 \mathrm{~min}$. PCR products were analyzed on $1 \%(\mathrm{w} / \mathrm{v})$

132 agarose-synergel gels and visualized under UV light after staining with UView loading dye (166-

133 5112, Biorad). PCR products were cloned using the TOPO-TA cloning kit (K4500-01,

134 Invitrogen) and sequenced for both strands. The obtained sequence was submitted to the National 
135 Center for Biotechnology Information (NCBI) database for BLAST searching and other

136 informatics analysis.

137

138

In silico analyses. Identification of the open reading frame was performed using the ORF

finder software (https://www.ncbi.nlm.nih.gov/orffinder/) and sequence alignment with

homologous sequences were performed by using CLUSTAL Omega. Identification of putative

protein motifs was performed using the MotifScan (Pfam HMMs global models database)

142

available at the Swiss Institute of Bioinformatic (http://myhits.isb-sib.ch/cgi-bin/motif_scan).

Identification of signal peptide was achieved by using SignalP 4.1 Server (Petersen et al., 2011).

Theoretical molecular weight, isoelectric point (pI), and amino acid composition of the protein

were calculated using the ProtParam software from ExPASy (Expert Protein Analysis System;

https://www.expasy.org/). Putative glycosylation and phosphorylation sites of N66 were

determined using NetOGly4.0 (Steentoft et al., 2013), NetNGlyc 1.0

(http://www.cbs.dtu.dk/services/NetNGlyc/) and NetPhos2.0 (Blom, Gammeltoft \& Brunak, 1999), respectively. 
158 construct and cultured in $6 \mathrm{~mL}$ of $\mathrm{LB}$ medium containing $100 \mu \mathrm{g} / \mathrm{mL}$ ampicillin at $37^{\circ} \mathrm{C}$ with

159 shaking at $150 \mathrm{rpm}$ overnight. Five $\mathrm{mL}$ of the culture medium were transferred to a flask

160 containing $245 \mathrm{~mL}$ of the same medium and further incubated. When $\mathrm{OD}_{600}$ of the bacterial cells

161 reached $\sim 0.7$, isopropyl $\beta$-D-thiogalactosidase was added to a final concentration of $1 \mathrm{mM}$ and

162 incubated at $37^{\circ} \mathrm{C}$ with constant shaking at $150 \mathrm{rpm}$ for $4 \mathrm{~h}$. The bacterial cells were harvested

163 by centrifugation $\left(7,500 \mathrm{rpm}, 25 \mathrm{~min}\right.$ at room temperature) and stored at $-20{ }^{\circ} \mathrm{C}$. The frozen

164 bacterial pellet was thawed and dispersed in ice-cold Tris-HCl buffer (50 mM, pH 7.4) and

165 disrupted with glass beads for 5 min of vigorous vortexing. The bacterial lysate was centrifuged

$166\left(12,000 \mathrm{rpm}, 15 \mathrm{~min}, 4^{\circ} \mathrm{C}\right)$, and the supernatant was recovered. Recombinant His-tagged

167 proteins were purified from the supernatant by using a Sepharose-Ni column (GE Healthcare).

168

169

Native N66 purification and characterization

Shell matrix extraction. The organic matrix of prismatic and nacreous layers were crushed to fine powder. The powdered matrix $(20 \mathrm{~g})$ were suspended in $100 \mathrm{~mL}$ cold acetic acid

$172\left(4{ }^{\circ} \mathrm{C}, 10 \% \mathrm{v} / \mathrm{v}\right)$ and incubated for $24 \mathrm{~h}$ with continuous stirring. Soluble (ASM) and insoluble

173 (AIM) matrix fractions were separated by centrifugation at 14,000 rpm for 20 minutes. The AIM was rinsed with distilled water and lyophilized. The ASM was dialyzed $24 \mathrm{~h}$ against cold acetic acid $\left(4{ }^{\circ} \mathrm{C}, 1 \% \mathrm{v} / \mathrm{v}\right)$, afterwards the ASM was dialyzed other $24 \mathrm{~h}$ against distilled water. The dialyzed ASM was concentrated by lyophilization. Protein concentration was determined by

177 Lowry method (Lowry et al., 1951).

178 
$181 \mathrm{~cm})$. Protein sample $(1 \mathrm{~mL})$ was loaded onto the column, previously equilibrated with $50 \mathrm{mM}$

182 Tris- $\mathrm{HCl} \mathrm{pH} \mathrm{7.4,} 300 \mathrm{mM} \mathrm{NaCl}$ buffer, mixed and incubated for $1 \mathrm{~h}$ at $25^{\circ} \mathrm{C}$. The unbound 183 enzyme was washed with five bed volumes of $50 \mathrm{mM}$ Tris-HCl pH 7.5, $300 \mathrm{mM} \mathrm{NaCl}$ buffer.

184 The bound enzyme was eluted by washing the column with elution buffer containing $50 \mathrm{mM}$ 185 Tris- $\mathrm{HCl} \mathrm{pH} 7.5,300 \mathrm{mM} \mathrm{NaCl}, 300 \mathrm{mM}$ Imidazole. Fractions of $1 \mathrm{~mL}$ were collected from the

186 elution and evaluated by electrophoresis. Fractions containing N66 were pooled and concentrated 187 through centrifugal filters (AMICON Ultra-10, Millipore) at 4,000 g for $20 \mathrm{~min}$ at $25^{\circ} \mathrm{C}$ to a 188 final volume of $500 \mu \mathrm{L}$. Concentrated sample was desalted using PD-10 desalting column 189 (Amershan Pharmacia). Glycerol was added to the enzyme solution (final concentration 50\%), 190 and the sample was stored at $-20{ }^{\circ} \mathrm{C}$ until use. Protein content was quantified by Lowry method 191 (Lowry et al., 1951) and SDS-PAGE analysis of the purified protein was performed as described 192 above.

SDS-PAGE and staining. Protein bands, from native and recombinant proteins, were analyzed by electrophoresis under reducing conditions using 10\% SDS-PAGE (MiniPROTEAN, Bio-Rad), as described by Laemmli (1970) and stained with silver nitrate (Merril \& Washart, 1998) in 10\% acrylamide gels. Samples were diluted (1:4) with sample buffer (0.125 M Tris- $\mathrm{HCl}, 2 \%$ SDS, 20\% v/v glycerol, $0.04 \%$ bromophenol blue, 5\% $\beta$-mercaptoethanol at $\mathrm{pH}$ 6.8) and heated for $10 \mathrm{~min}$ at $100{ }^{\circ} \mathrm{C}$. Electrophoresis separation was performed at $80 \mathrm{~V}$ constant current. To detect protein bands, gels were stained with 0.1\% Coomassie Brilliant Blue R-250 in $40 \%$ methanol. 
203 Glycosylation was analyzed by electrophoresis under reducing conditions (Thornton et al.,

204 1994). The gel was first incubated in fixing solution (5\% TCA) for $5 \mathrm{~min}$, then incubated in

205 oxidant solution $(0.8 \%$ periodic acid in $0.3 \%$ sodium acetate $)$, and rinsed with water. Then the

206 gel was incubated in Schiff's reagent for 10 min in the dark. Finally, the gel was washed three

207 times with 3\% nitric acid for $3 \mathrm{~min}$. The gel was stored in 7.5\% acetic acid, 5\% v/v methanol.

208 Ovoalbumin (SIGMA) was used as positive control.

209

210

Mass spectrometry analyses. To identify the mass spectrometric profile, $20 \mu \mathrm{g}$ of the

native N66 protein was first separated by 10\% SDS-PAGE. After electrophoresis, the gel was

stained with Coomassie Blue R-250 and bands were manually cut from the gel. After tryptic

digestion, the resulting peptides were subjected to Liquid Chromatography-Mass Spectrometry

(LC-MS). The LC-MS was performed at the Proteomic Unit Facility at Biotechnology Institute,

Cuernavaca. The resulting data were compared with the proteomic database at GenBank and

with the deduced amino acid sequence from cDNA of N66 from P. mazatlanica.

Carbonic anhydrase assay. Carbonic anhydrase activity from native and recombinant

N66 was assayed qualitatively and quantitatively. For qualitative assay, $1 \%$ agarose plates were prepared with borate buffer $(0.05 \mathrm{M}$ boric acid, $0.025 \mathrm{M} \mathrm{NaCl})$. Samples $(10 \mu \mathrm{L}$ of $0.2 \mathrm{mg}$ protein $/ \mathrm{mL}$ ) were loaded on the agar plate, after sample diffusion $0.1 \%$ bromocresol purple (dissolved in $0.1 \mathrm{M}$ Tris- $\mathrm{HCl} \mathrm{pH} 8.5$ ) was added and incubated for $10 \mathrm{~min}$ at room temperature.

Afterwards, the solution was discarded and the agar plate was washed with distilled water.

Finally, saturated $\mathrm{CO}_{2}$ water was added as substrate; the production of hydrogen ions during the

$225 \mathrm{CO}_{2}$ hydration reaction lowers the $\mathrm{pH}$ of the solution until the formation of yellow halo zones 
226 which indicate carbonic anhydrase activity while dark zone indicate lack of activity (Machenko,

227 2002). Bovine carbonic anhydrase (SIGMA) was used as positive control and boiled enzyme as

228 negative control.

229 The quantitative in vitro assay for CA activity is described in detail by Wilbur and 230 Anderson (1948). Briefly, CA activity was measured by the decrease of $\mathrm{pH}$ resulting from the

231 hydration of $\mathrm{CO}_{2}$ to $\mathrm{HCO}_{3}{ }^{-}$and $\mathrm{H}^{+}$after the addition of substrate. All experiments were

232 performed at $4{ }^{\circ} \mathrm{C}$. To run the assay, $5 \mathrm{~mL}$ of $0.012 \mathrm{M}$ Tris- $\mathrm{HCl}$ buffer $(\mathrm{pH} 8.3)$ were transferred

233 to a small beaker and $1 \mathrm{~mL}$ of homogenate diluted in $0.012 \mathrm{M}$ Tris-HCl buffer was added to

234 obtain $20 \mu \mathrm{g}$ of protein. The mixture was constantly stirred with a magnetic stirring bar.

235 Afterwards, $4 \mathrm{~mL}$ of cold saturated $\mathrm{CO}_{2}$ solution were added, and the decrease in $\mathrm{pH}$ was

236 recorded by a $\mathrm{pH}$ probe. CA activity was calculated as $\left(\mathrm{t}_{0^{-}} \mathrm{t}\right) / \mathrm{t}$, where $\mathrm{t}_{0}$ is the time needed for the

237 non-catalyzed reaction and $\mathrm{t}$ is the time for the catalyzed reaction to obtain a $\mathrm{pH}$ decrease from

2388.0 to 6.0. Units of enzyme activity (U) were normalized to the total protein content.

Crystallization in vitro assay with native and recombinant N66. Three crystallization

solutions were prepared, two induces calcite (calcitic crystallization solution) and one induces aragonite (aragonite crystallization solution). Calcitic crystallization solutions (40 $\mathrm{mM} \mathrm{CaCl}, \mathrm{pH}$

8.2, $100 \mathrm{mM} \mathrm{NaHCO}_{3}$ and $\left.100 \mathrm{mM} \mathrm{CaCO}_{3}\right)$ and aragonite crystallization solution $(40 \mathrm{mM}$ and Hillner et al. 1992, respectively. Native and recombinant N66 (10 $\mu \mathrm{L}$ of $0.2 \mathrm{mg} / \mathrm{ml})$ were added to $50 \mu \mathrm{L}$ of the saturated solution. As a control, buffer solution without protein was used.

247 Each solution experiment was made in triplicates and incubated at $4{ }^{\circ} \mathrm{C}$ for 21 days in a cover

248 slide situated at the bottom of a six-hole microplate which was sealed with parafilm to avoid 
249 contamination. The morphology of the crystals produced were analyzed by scanning electron

250 microscopy (SEM) at the Electronic Microscopy Laboratory at CIBNOR.

251

252 Statistical analysis

253 Statistical analysis was performed using the GraphPad Prism Software. The results are expressed

254 as means \pm s.d. Significant differences $(\mathrm{P}<0.05)$ were determined by ANOVA followed by a

255 pair-wise comparison of means (Tukey’s test).

256

257 Results

258

Sequence analysis of cDNA from mantle of Pinctada mazatlanica encoding a N66.

259

260

261

262

263

264

265

266

267

268

269

270

271

Nucleotides and deduced amino acid sequence of N66 from the mantle of P. mazatlanica are shown in Fig. 1. The open reading frame of N66 obtained from mantle cDNA was 1766 bp long (GenBank: MH473230) and encoded a 576 amino acid protein with a calculated molecular mass of $63.68 \mathrm{kDa}$ before any post-translational modification and an isoelectric point (pI) of 7.38. Removal of the signal peptide sequence (residues 1 to 22) resulted in a theoretical molecular weight of $61.12 \mathrm{kDa}$ and a theoretical $\mathrm{pI}$ of 7.21. It possess high proportions of $\mathrm{N}(19.6 \%)$ and $\mathrm{G}$ (15.8\%), which accounted for $35.4 \%$ of the total amino acid residues (Table 2 ). Analysis of the N66 amino acid sequence showed homology with the carbonic anhydrase (CA) family, exhibiting 34\% identity with human CAVII (GenBank: NP_005173), with high homology to amino acid residues involved in catalysis $\left(\mathrm{Q}_{125}, \mathrm{~N}_{154}\right.$ and $\left.\mathrm{E}_{168}\right)$ and three histidine residues essential for the zinc cofactor binding $\left(\mathrm{H}_{156}, \mathrm{H}_{158}\right.$ and $\left.\mathrm{H}_{181}\right)$ (Fig. 1).

N66 protein sequence possess in its modular structure a signal peptide (1-22 aa), two carbonic anhydrase domains $\left(\mathrm{G}_{69}-\mathrm{G}_{221}\right.$ and $\left.\mathrm{D}_{490}-\mathrm{K}_{554}\right)$, and a $\mathrm{NG}$ rich sequence $\left(\mathrm{N}_{245}-\mathrm{G}_{437}\right)$ (Fig. 
272 S1), sharing $82.82 \%$ identity to N66 from P. maxima, $\sim 92 \%$ to nacreins (B2, B3 and B4) from

273 Pinctada margaritifera, $72.62 \%$ to nacrein from Pinctada fucata and $78.70 \%$ to N45 from $P$.

274 maxima (Fig. 2). All the protein sequences contained the same protein structure, however the

275 length of the carbonic anhydrase (CA) and NG domain were variable among the proteins.

276 Further bioinformatics analysis of the N66 sequence suggests that some serine and threonine

277 residues in N66 may either be phosphorylated (36 putative sites) or N- and O-glycosylated (16

278 putative sites), as indicated in Fig. 1, which are common features related to proteins involved in

279 biomineralization (Nudelman et al., 2007). Finally, most of the O-glycosylation and

280 phosphorylation sites were found in the CA domain.

281

282

283

284

285

286

287

288

289

290

291

292

293

294

\section{N66 protein characterization}

Native N66 from $P$. mazatlanica shells. The organic matrix of the shell from $P$.

mazatlanica was separated by SDS-PAGE revealing a wide range of abundant molecular weight proteins in the ASM fraction (Fig. 3A). The ASM fraction was used to isolate the N66 by affinity chromatography using a Sepharose-Ni matrix (Fig. S2) since the active site of the CA domain contains three histidines involved in metal ion binding which has been shown to be conserved in N66 from P. mazatlanica (this study) and P. maxima (Kono, Hayashi \& Samata, 2000). The fractions containing the eluted N66 (Fig. S2) were pooled and desalted. Two bands in SDSPAGE and silver stained gels were observed (Fig. 3B) with molecular weights of $\sim 60$ and 64 $\mathrm{kDa}$. A flow sheet of the purification process for N66 is presented in Table 3. The enzyme was enriched 3.39-fold and the yield was 56.52\%. Electrophoretic analysis of N66 with PAS stain, demonstrated that N66 is glycosylated (Fig. 3B), however, the type of carbohydrate associated was not analyzed. The results of LC-MS of the bands matched the deduced amino acid sequence 
295 of the N66 of the mantle of P. mazatlanica (Table 4), as described before (Fig. 1), and allowed

296 us to identify it as a N66, a shell matrix protein from the shell of $P$. mazatlanica.

297

298

299

300

301

302

303

304

305

306

307

308

309

310

311

312

313

314

315

316

317

7

Recombinant N66 from $P$. mazatlanica. Recombinant N66 protein was expressed as a soluble form at $37{ }^{\circ} \mathrm{C}$ with $1 \mathrm{mM}$ IPTG in E. coli after $4 \mathrm{~h}$ induction, and the bands corresponding to the protein in SDS-PAGE analysis agreed with the native N66 of ASM from $P$. mazatlanica (Fig. 3B). The recombinant N66 was successfully purified to homogeneity by affinity chromatography using Ni-Sepharose columns (Fig. S3). Electrophoretic analysis showed two protein bands of $\sim 60$ and $64 \mathrm{kDa}$ which agreed with that of the native N66 of ASM from $P$. mazatlanica (Fig. 3B). Recombinant N66 did not show glycosylation after staining with PAS (data not shown).

Carbonic anhydrase activity of native and recombinant N66. The carbonic anhydrase activity of the native and recombinant N66 was confirmed qualitatively (Fig. 4) and quantitatively. Figure 4 showed comparable yellow halos obtained with the native and recombinant N66, indicating CA activity. The commercial bovine CA was used as positive control. The comparable CA activity of the native and recombinant N66 proteins was confirmed with the Wilbur and Anderson method. The results showed significant differences between native $(161 \pm 12.5 \mathrm{U} / \mathrm{mg}$ protein) and recombinant protein $(197 \pm 7.5 \mathrm{U} / \mathrm{mg}$ protein), being the recombinant protein the one with higher activity.

In vitro crystallization by native and recombinant $\mathrm{N66}$. To elucidate the effect of native and recombinant N66 on the growth of calcium carbonate crystals, three individual in vitro crystallization assays testing the formation of aragonite and calcite were established and 
318 analyzed by SEM (Fig. 5). First, when no protein was added (negative control) to the three salts

319 tested $\left(\mathrm{NaHCO}_{3}+\mathrm{MgCl}_{2}, \mathrm{NaHCO}_{3}+\mathrm{CaCl}_{2}\right.$ and $\left.\mathrm{CaCO}_{3}\right)$, different crystal morphology was

320 observed. The crystals formed when sodium bicarbonate in presence of magnesium chloride

321 were unorganized, while in presence of calcium chloride crystals become compact and thicker,

322 and in presence of calcium carbonate the formed crystals exhibited the typical rhombohedra of

323 calcite (Fig. 5A-C). On the other hand, in the presence of $0.2 \mathrm{mg}$ protein/ $\mathrm{mL}$ of native N66 to

324 the three salts preparations showed polycrystalline aggregates of aragonite and calcite in

325 presence of $\mathrm{MgCl}_{2}$ and $\mathrm{CaCO}_{3}$ respectively, however in presence of $\mathrm{CaCl}_{2}$, crystals were small

326 structures of calcite and in lesser quantity per area (Fig. 5D-F). In contrast to native N66,

327 recombinant form produced bigger and organized crystal structures forming plates (Fig. 5G-I).

\section{Discussion}

The mollusk shell is a complex structure made of organic and mineral components. The shells are composed by layers formed from calcium carbonate polymorphs as aragonite or calcite crystals (Takeuchi et al., 2008; Zhang \& Zhang, 2006). The calcium carbonate polymorphs are formed by shell matrix proteins (SMPs), which have been classified as soluble and insoluble based on the two main extraction methods, EDTA and acetic acid (Marie et al., 2007; Kono, Hayashi \& Samata, 2000). The insoluble proteins, are chitin-proteinaceous complexes rich in aliphatic amino acids, such as Gly and Ala, while the soluble proteins have been found to be polyanionic, enriched mainly in Asp; among the soluble proteins, functional enzymes such as carbonic anhydrases have been described (Kono, Hayashi \& Samata, 2000), which seems contribute to the control of biomineralization. mollusks is available for nacreins (Mann, Edsinger-Gonzalez \& Mann, 2012; Leggat et al., 2005; 
341 Miyamoto et al., 1996). Nacrein gene has been described in Crassostrea gigas (Song et al.,

342 2014), Patella vulgata, Mytilus californianus, P. maxima and Pinctada magaritifera (Joubert et

343 al., 2010), while N66 mRNA has been only described in P. maxima (Kono, Hayashi \& Samata,

344 2000) and P. margaritifera (Joubert et al., 2010). This homologous genes have been found to be

345 expressed in the mantle (Miyamoto, Myoshi \& Kohno, 2005; Kono, Hayashi \& Samata, 2000),

346 which is a conserved organ involved in shell formation throughout mollusks. We followed this

347 lead and proved that $P$. mazatlanica express the N66 mRNA in the mantle and secrete the

348 enzyme into the extrapalleal space to participate in the shell growth.

349 Currently, only six SMPs with carbonic anhydrase activity have been isolated and

350 characterized from pearl oysters, nacrein from the Akoya pearl oyster Pinctada fucata, turban

351 shell Turbo marmoratus, the edible Iwagaki oyster Crassostrea nippona, Yesso scallop

352 Patinopecten yessoensis and giant clam Tridacna gigas (Norizuki \& Samata; Leggat et al., 2005;

353 Miyamoto et al., 2003; Miyamoto et al., 1996), and only one N66 from P. maxima (Miyamoto et

354 al., 1996). Carbonic anhydrases (CAs) are usually purified via the agarose-sulfonamide affinity

355 column chromatographic procedure (Ozensoy, Capasso \& Supuran, 2016), however, in this study

356 a Sepharose-Ni column was successfully used to capture the N66 protein from the shell of $P$.

357 mazatlanica, since it is well known that the CA domain possess three conserved histidine

358 residues at the active site and His exhibits the strongest interaction to metal ion matrices, as

359 electron donors groups on the imidazole ring of His form coordinated bonds with the

360 immobilized metal (Bornhorst \& Falke, 2000). The isolated protein was identified by mass

361 spectrometry as a N66, due to its similarity to N66 from P. maxima and its homolog protein,

362 nacrein; native N66 and its recombinant form showed two bands with a molecular weight of $\sim 60$

363 and $\sim 66 \mathrm{kDa}$, respectively. The double bands of the proteins observed on SDS-PAGE under 
364 reducing conditions have been also observed in other CAs such as CAH1, CAXII and CAIX, the

365 last one migrates as a double band between $54 / 58 \mathrm{kDa}$ under reducing conditions. This effect is

366 most likely due to glycosylations (Buren et al., 2011; Ulmasov et al., 2000) and/or equivalent

367 populations of mature and pro-forms of the enzyme with both possessing a propensity to

368 oligomerize in non-reducing conditions (Hilvo et al., 2008; Ulmasov et al., 2000; Pastorek et al.,

369 1994). Since the recombinant N66 do not possess PTM and both, native and recombinant,

370 migrate similar on SDS-PAGE, the formation of oligomers of N66 is suggested in this study.

371 However, further experiments are required to establish if the double band of N66 from the shell

372 of P. sterna is due to glycosylations or oligomerization of the protein.

Structurally, N66 in P. mazatlanica is similar to N66 from P. maxima (Kono, Hayashi \&

Samata, 2000) and its homologous proteins, nacreins and N45 (Miyamoto et al., 1996), they

contain a domain which is composed by three amino acid residues (Gln, Asn and Glu) and three

377 His (Vulo et al., 2008), according to the deduced primary structure of N66 from P. mazatlanica, the protein contains two CA domains composed by $\mathrm{Gln}_{125}, \mathrm{Asn}_{154}, \mathrm{Glu}_{168}$ and three His residues which act as zinc ligands (His ${ }_{156}, \mathrm{His}_{158}$ and His 181 ), suggesting that N66 possess a functional CA domain. CA activity has been only proved in nacrein from P. fucata (Miyamoto et al., 1996) and N66 from P. mazatlanica and its recombinant protein, in this study. The recombinant N66 showed higher CA activity than the native N66 and the bovine CA. The NG domain found in N66 from $P$. mazatlanica differs in length and composition to its homologues, accounting for over $\sim 30 \%$ of their sequences. This domain has been proved to function as negative regulator in shell formation in nacrein (Miyamoto, Miyoshi \& Kohno, 2005), but also as a positive regulator, 
$387 \&$ Samata, 2008). It is hypothesized that the longer repeat NG domain might have a stronger

388 interaction of protein with $\mathrm{Ca}^{2+}$ molecules, matrix components and crystals, leading to better

389 calcification ability (Samata et al., 1999). This suggests, that N66 might have better calcification

390 ability than its homologs, although, further experiments are required to prove this hypothesis.

391 Post-translational modifications (PTM) of SMPs are a common feature that have been

392 suggested to play an important role in biomineralization. Phosphorylation and glycosylation are

393 the major players in many of the protein functions (Saraswathy \& Ramalingam, 2011). In silico

394 analysis of N66 from $P$. mazatlanica showed 36 putative sites of phosphorylation and 16

395 putative sites of glycosylation. The biochemical analysis confirmed that N66 is glycosylated

396 (Fig. 3B), a modification that has been observed in other matrix proteins (Montagnani et al.,

397 2011; Suzuki et al., 2011). Glycosylation participates in the folding of the protein and/or

398 interactions with $\mathrm{Ca}^{2+}$ (Suzuki et al., 2011; Borbas, Wheeler \& Sikes, 1991) and provide sites of

399 high anionic charge through addition of sialic acid or sulfated oligosaccharides (Michenfelder et

400 al., 2003) which have been related to promote the uptake of $\mathrm{Ca}^{2+}$ (Song et al., 2014). The

401 saccharide chains of N66 in P. mazatlanica probably have similar effects, however, the chemical

402 identity of the oligosaccharides moieties, the number and the location of actual glycosylation

403 sites along the protein of N66 remain to be determined.

404 Experiments involving in vitro calcium carbonate crystallization have been used to prove

405 functional activity of SMPs since most of the described SMPs does not possess catalytic

406 domains. Crystal formation comprise two main process, nucleation and growth. It begins with an

407 amorphous calcium carbonate as an intermediate of the crystalline carbonate polymorph such as

408 calcite or aragonite (Wang et al., 2009). The presence of $\mathrm{Mg}^{2+}$ ions foster metastable aragonite

409 growth that make up the mineral phase of nacre (Evans, 2017; Su et al., 2016; Samata et al., 
410 1999), and when $\mathrm{Mg}^{2+}$ ion are low induces the formation of calcite (Raz, Weiner \& Addadi,

411 2000). Morphological observation of calcite and aragonite by SEM has been made by several

412 authors, showing that crystals of calcite display a rombohedral form while aragonite has an

413 orthorhombic form (Zigovecki, Posilovic \& Bermanee, 2009), although the morphology of each

414 polymorph can be changed due to the crystallization condition, e.g. aragonite is needle-like but it

415 changes to flake-like or cauliflower-like (Chakrabarty \& Mahapatra, 1999). In this study, N66

416 and its recombinant protein have differential CA activity and lead to calcium carbonate

417 precipitation, displaying structures such as aragonite and calcite when crystallization was made

418 in presence of $\mathrm{MgCl}_{2}$ and $\mathrm{CaCl}_{2}$, respectively. Similar results were obtained by Kono et al.

419 (2000), for N66 from P. maxima, which induces aragonite layers, however it requires the

420 presence of $\mathrm{N} 14$ and $\mathrm{Mg}^{2+}$ ions. The recombinant $\mathrm{N} 66$ foster higher crystal growth than native

421 N66, this evidence raise the possibility that the presence of PTMs (e.g. glycosylations and

422 phosphorylations) affect the growth and shape of calcite and aragonite crystals, which is in

423 agreement to previous evidences in Unio pictorum, that showed that glycosylations might change

424 the crystal morphology in in vitro crystallization experiments (Marie et al., 2007).

\section{Conclusion}

In this study, a N66 mRNA from the mantle of P. mazatlanica was identified. The

427

428

429

430

431

432 transcript is translated to one single protein named N66. The N66 is a glycoprotein with carbonic anhydrase activity and calcium carbonate precipitation ability in vitro, suggesting that N66 is involved in the mineralization process in P. mazatlanica. Experiments with the recombinant N66 suggest that posttranslational modifications might play an important role in the modulation of the CA activity. The identification of the carbohydrates associated to N66, as well as the determination of other posttranslational modification (e.g. phosphorylation, sulfation, etc.), and 
433 their role in the calcium carbonate precipitation (e.g. crystal growth, type of polymorph) remains

434 to be tested. Also, to understand the potential oligomerization process of the N66 and its role in 435 the mineralization process remains unclear.

436

\section{References}

438 Addadi L, Joester D, Nudelman F, Weiner S. 2006. Mollusk shell formation: A source of new 439 concepts for understanding biomineralization processes. Chemistry European Journal 12:980440 987. DOI: $10.1002 /$ chem.200500980.

441 Blom N, Gammeltoft S, Brunak S. 1999. Sequence- and structure-based prediction of eukaryotic 442 protein phosphorylation sites. Journal of Molecular Biology 294:1351-1362. DOI:

443 10.1006/jmbi.1999.3310.

444 Borbas JE, Wheeler AP, Sikes S. 1991. Molluscan shell matrix phosphoproteins: Correlation of 445 degree of phosphorylation to shell mineral microstructure and to in vitro regulation of 446 mineralization. Journal of Experimental Zoology 258:1-13. DOI:10.1002/jez.1402580102.

447 Bornhorst JA, Falke JJ. 2000. Purification of proteins using polyhistidine affinity tags. Methods 448 in Enzymol 326:245-254.

449 Buren S, Ortega-Villasante C, Blanco-Rivero A, Martinez-Bernardini A, Shutova T, 2011.

450 Importance of post-translational modifications for functionality of a chloroplast-localized

451 carbonic anhydrase (CAH1) in Arabidopsis thaliana. PLOS One 6(6): e21021. DOI:

452 10.1371/journal.pone.0021021

453 Chakrabarty D, Mahapatra S. 1999. Aragonite crystals with unconventional

454 morphologies. Journal of Materials Chemistry 9:2953-2957. DOI: 10.1039/a905407c 
455 Checa AG, Macías-Sánchez E, Ramírez-Rico J. 2016. Biological strategy for the fabrication of

456 highly ordered aragonite helices: the microstructure of the cavolinioidean gastropods. Scientific 457 Reports 6:25989. DOI: 10.1038/srep25989.

458 De Luca V, Del Prete S, Vullo D, Carginale V, Di Fonzo P, Osman SM, AlOthman Z, Supuran 459 CT, Capasso C. 2016. Expression and characterization of a recombinant psychrophilic carbonic 460 anhydrase (NcoCA) identified in the genome of the Antarctic cyanobacteria belonging to the 461 genus Nostoc. Journal of Enzyme Inhibition and Medical Chemistry, 31(5): 810-817. DOI: $46210.3109 / 14756366.2015 .1069289$.

463 Evans JS. 2017. Polymorphs, proteins, and nucleation theory: A critical analysis. Minerals. 7: 6. 464 DOI: $10.3390 / \min 7040062$.

465 Hillner PE, Manne S, Gratz AJ, Hansma PK. 1992. AFM images of dissolution and growth on a 466 calcite growth crystal. Ultramicroscopy 42:1387-1393. DOI: 10.1016/0304-3991(92)90454-R.

467 Hilvo M, Baranauskiene L, Salzano AM, Sacloni A, Matulis D, Innocenti A, Scozzafava A, Monti 468 SM, Di Fiore A, De Simone G, Lindfors M, Janis J, Valjakka J, Pastorekova S, Pastorek J, 469 Kulomaa MS, Nordlund HR, Supuran CT, Parkkila S. 2008. Biochemical characterization of 470 CAIX, one of the most active carbonic anhydrase isozymes. Journal of Biological Chemistry 41: 471 27799-27809. DOI: 10.1074/jbc.M800938200.

472 Joubert C, Piquemal D, Marie B, Manchon L, Pierrat F, Zanella-Cleon I, Cochennec-Laureau N, 473 Gueguen Y, Montagnani C. 2010. Transcriptome and proteome analysis of Pinctada 474 margaritifera calcifying and shell: focus on biomineralization. BMC Genomics 11:613. DOI: $47510.1186 / 1471-2164-11-613$. 
476 Kono M, Hayashi N, Samata T. 2000. Molecular Mechanism of the Nacreous Layer Formation

477 in Pinctada maxima. Biochemical and Biophysical Research Communications 269:213-218.

478 DOI: $10.1006 /$ bbrc.2000.2274.

479 Laemmli UK. 1970. Cleavage of structural proteins during the assembly of the head of

480 bacteriophage T4. Nature 227:680-685. DOI: 10.1038/227680a0.

481 Leggat W, Dixon R, Saleh S, Yellowlees D. 2005. A novel carbonic anhydrase from the giant

482 clam Tridacna gigas contains two carbonic anhydrase domains. FEBS Journal 272:3297-3305.

483 DOI: 10.1111/j.1742-4658.2005.04742.x.

484 Liu X, Liu C, Chen L, Sun J. 2011. A new method to extract matrix proteins directly from the

485 secretion of the mollusk mantle and the role of these proteins in shell biomineralization. Marine

486 Biotechnology 13:981-991. DOI: 10.1007/s10126-011-9362-y.

487 Lowry OH, Rosebrough NJ, Farr AL, Randall RJ. 1951. Protein measurement with the folin

488 phenol reagent. Journal of Biological Chemistry 193:265.

489 Manchenko GP. 2002. Handbook of detection of enzymes on electrophoretic gels, Boca Raton:

490 CRC Press.

491 Mann K, Edsinger-Gonzalez E, Mann M. 2012. In depth proteomic analysis of a molluscan shell:

492 acid-soluble and acid-insoluble matrix of the limpet Lottia gigantea. Proteome Science 10:28.

493 DOI: 10.1186/1477-5956-10-28.

494 Marie B, Luquet G, Pais de Barros JP, Guichard N, Morel S, Alcaraz G, Bollache L, Marin F.

495 2007. The shell matrix of the freshwater mussel Unio pictorum (Paleoheterodonta, Unionoida).

496 FEBS Journal 274:2933-2945. DOI: 10.1111/j.1742-4658.2007.05825.x.

497 Merril CR, Washart KM. 1998. Gel electrophoresis of proteins: a practical approach. IN Press,

498 O.U. (Ed.) New York. 
499 Michenfelder M, Fu G, Lawrence C, Weeaver JC, Wustman BA, Taranto L, Evans JS, Morse

500 DE. 2003. Characterization of two molluscan crystal-modulating biomineralization proteins and

501 identification of putative mineral binding domains. Biopolymers 70:522-533. DOI:

502 10.1002/bip.10536.

503 Miyamoto H, Miyashita T, Okushima M, Nakano S, Morita T, Matsushiro A. 1996. A carbonic

504 anhydrase from the nacreous layer in oyster pearls. Proceedings of the National Academy of

505 Sciences 93:9657-9660.

506 Miyamoto H, Yano M, Miyashita T. 2003. Similarities in the structure of nacrein, the shell-

507 matrix protein, in a bivalve and a gastropod. Journal of Molluscan Studies 69:87-89. DOI:

508 10.1093/mollus/69.1.87.

509 Miyamoto H, Miyoshi F, Kohno J. 2005. The carbonic anhydrase domain protein nacrein is 510 expressed in the epithelial cells of the mantle and acts as a negative regulator in calcification in

511 the mollusc Pinctada fucata. Zoological Science 22:311-315. DOI: 10.2108/zsj.22.311.

512 Miyamoto H, Endo H, Hashimoto N, Limura K, Isowa Y, Kinoshita S, Kotaki T, Masaoka T,

513 Miki T, Nakayama S, Nogawa C, Notazawa A, Ohmori F, Sarashina I, Suzuki M, Takagi R,

514 Tkahashi J, Takeuchi T, Yokoo N, Satoh N, Toyohara H, Miyashita T, Wada H, Samata T, Endo

515 K, Nagasawa H, Watabe S. 2013. The diversity of shell matrix proteins: genome-wide

516 investigation of the pearl oyster, Pinctada fucata. Zoological Science 30:801-816. DOI:

$517 \quad 10.2108 / \mathrm{zsj} .30 .801$.

518 Montagnani C, Marie B, Marin F, Belliard C, Riquet F, Tayalé A, Zanella-Cleon I, Fleury E,

519 Gueguen Y, Piquemal D, Cochennec-Laureau N. 2011. Pmarg-Pearlin is a matrix protein

520 involved in nacre framework formation in the pearl oyster Pinctada margaritifera.

521 ChemBioChem. 2011; 12:2033-2043. DOI: 10.1002/cbic.201100216. 
522 Mutvei H. 1980. The nacreous layer in molluscan shells. In: The mechanisms of

523 biomineralization in animals and plants. Proceedings of the third international biomineralization

524 symposium, pp. 49-56. Tokai University Press, Tokyo.

525 Norizuki M, Samata T. 2008. Distribution and function of the nacrein-related proteins inferred

526 from structural analysis. Marine Biotechnology 10:234-241. DOI: 10.1007/s10126-007-9061-x.

527 Nudelman F, Chen HH, Goldberg SW, Addadi L. 2007. Memorial lecture lessons from

528 biomineralization: comparing the growth strategies of mollusc shell prismatic layers in Atrina

529 rigida. Faraday Discussions 136:9-25.

530 Ozensoy GO, Capasso C, Supuran CT. 2016. A magnificent enzyme superfamily: carbonic

531 anhydrase, their purification and characterization. Journal of Enzyme Inhibition and Medicinal

532 Chemistry 31:5, 689-694. DOI: 10.3109/14756366.2015.1059333.

533 Pastorek J, Pastorekova S, Callebaut I, Mornon JP, Zelnik V, Opavsky R, Zatovicova M, Liao S,

534 Portetelle D, Stanbridge EJ. 1994. Cloning and characterization of MN, a human tumor-associated

535 a protein with a domain homologous to carbonic anhydrase and a putative helix-loop-helix DNA

536 binding segment. Oncogene, 9(10): 2877-2888.

537 Petersen TN, Brunak S, von Heijne G, Nielsen H. 2011. SignalP 4.0: discriminating signal

538 peptides from transmembrane regions. Nature Methods 8:785-786. DOI: 10.1038/nmeth.1701.

539 Raz S., Weiner S., Addadi L. 2000. Formation of high magnesian calcites via an amorphous

540 precursor phase. Possible biological Implications. Advanced Materials 12, 38-42. DOI:

541 10.1002/(SICI)1521-4095(200001)12:1<38::AID-ADMA38>3.0.CO;2-I.

542 Samata T, Hayashi N, Kono M, Hasegawa K, Horita C, Akera S. 1999. A new matrix protein

543 family related to the nacreous layer formation of Pinctada fucata. FEBS Letters 462:225-229. 
544 Saraswathy N, Ramalingam P. Phosphoproteomics 2011. In: Concepts and Techniques in

545 Genomics and Proteomics 203-211.

546 Song X, Wang X, Li L, Zhang G. 2014. Identification two novel nacrein-like proteins involved

547 in the shell formation of the Pacific oyster Crassostrea gigas. Molecular and Biological Reports $548 \quad 41: 4273-4278$.

549 Steentoft C, Vakhrushev SY, Joshi HJ, Kong Y, Vester-Christensen MB, Schjoldager KT, 550 Lavrsen K, Dabelsteen S, Pedersen NB, Marcos-Silva L, Gupta R, Bennett EP, Mandel U, 551 Brunak S, Wandall HH, Levery SB, Clausen H. 2013. Precision mapping of the human O-

552 GalNAc glycoproteome through SimpleCell technology. EMBO Journal 32:1478-1488. DOI:

$553 \quad 10.1038 /$ emboj.2013.79.

554 Su J, Zhu F, Zhang G, Wang H, Xie L, Zhang R. 2016. Transformation of amorphous calcium 555 carbonate nanoparticles into aragonite controlled by ACCBP. Cryst Eng Comm 18:2125-2134.

556 DOI: 10.1039/C5CE02288F.

557 Sudo S, Fujikawa T, Nagakura T, Ohkubo T, Sakaguchi K, Tanaka M, Nakasima K, Takahashi

558 T. 1997. Structure of mollusc shell framework proteins. Nature 387:563-564. DOI:

$559 \quad 10.1038 / 42391$.

560 Suzuki M, Iwashima A, Tsutsui N, Ohira T, Kogure T, Nagasawa H. 2011. Identification and 561 characterization of a calcium carbonate-binding protein, blue mussel shell protein (BMSP), from 562 the nacreous layer. ChemBioChem 12:2478-2487. DOI: 10.1002/cbic.201100317.

563 Takakura D, Norizuki M, Ishikawa F, Samata T. 2008. Isolation and characterization of the N-

564 linked oligosaccharides in nacrein from Pinctada fucata. Marine Biotechnology 10:290-296.

565 DOI: 10.1007/s10126-007-9063-8. 
566 Takeuchi T, Sarashina I, Iijima M, Endo K. 2008. In vitro regulation of $\mathrm{CaCO}_{3}$ crystal

567 polymorphism by the highly acidic molluscan shell protein Aspein. FEBS Letters 582:591-596.

568 DOI: 10.1016/j.febslet.2008.01.026.

569 Thornton DJ, Carlstedt I, Sheehan JK. 1994. Identification of glycoproteins on nitrocellulose 570 membranes and gels. IN Jm, W. (Ed.) Method Molecular Biology. Totowa, NJ: Human Press.

571 Ulmasov B, Waheed A, Shah GN, Grubb JH, Sly WS, Tu C, Silverman DN. 2000. Purification 572 and kinetic analysis of recombinant CAXII, a membrane carbonic anhydrase overexpressed in 573 certain cancers. Proceedings of the National Academy of Sciences 97(26): 14212-14217.

574 DOI: 10.1073/pnas.97.26.14212

575 Vulo D, Nishimori I, Scozzafava A, Supuran CT. 2008. Carbonic anhydrase activators:

576 activation of the human cytosolic isozyme III and membrane-associated isoform IV with amino

577 acids and amines. Bioorganic \& Medicinal Chemistry Letters 18:4303-4307. DOI:

$578 \quad 10.1016 / \mathrm{j} . \mathrm{bmcl} .2008 .06 .075$.

579 Wang D, Wallace AF, De Yoreo JJ, Dove PM. 2009. Carboxylated molecules regulate 580 magnesium content of amorphous calcium carbonates during calcification. 106(51):21511-6.

581 DOI: 10.1073/pnas.0906741106.

582 Wilbur KM, Anderson NG. 1948. Electrometric and colorimetric determination of carbonic 583 anhydrase. Journal of Biological Chemistry 176:147-154.

584 Weiss IM, Kaufmann S, Mann K, Fritz M. 2000. Purification and Characterization of Perlucin 585 and Perlustrin, Two New Proteins from the Shell of the Mollusc Haliotis laevigata. Biochemical 586 and Biophysical Research Communications 267:17-21. DOI: 10.1006/bbrc.1999.1907. 
587 Xie J, Liang J, Sun J, Gao J, Zhang S, Liu Y, Xie L, Zhang R. 2016. Influence of the extrapallial 588 fluid of Pinctada fucata on the crystallization of calcium carbonate and shell biomineralization. 589 Crystal Growth \& Design 16:672-680. DOI: 10.1021/acs.cgd.5b01203.

590 Yarra T, Gharbi K, Blaxter M, Peck LS, Clark MS. 2016. Characterization of the mantle 591 transcriptome in bivalves: Pecten maximus, Mytilus edulis and Crassostrea gigas. Marine 592 Genomics 27:9-15. DOI: 10.1016/j.margen.2016.04.003.

593 Zhang C, Zhang R. 2006. Matrix proteins in the outer shells of molluscs. Marine Biotechnology 594 8:572-586. DOI: 10.1007/s10126-005-6029-6.

595 Zigovecki GZ, Posilovic H, Bermanee V. 2009. Identification of biogenetic calcite and aragonite 596 using SEM. Geologia Croatia 62(3): 201-206. DOI: 10.4154/gc.2009.14.

597

598

599

600

601

602

603

604

605

606

607

608

609

610

611 
612

613

614

615

616

617

618

619

620

621 
Figure 1 (on next page)

Nucleotide and deduced amino acid sequence in P. mazatlanica N66 cDNA (GenBank: MH473230).

The putative signal peptide is underlined. Conserved anhydrase carbonic domains are highlighted by shaded boxes. Triangles indicate amino acid residues involved in catalysis. Putative phosphorylation sites are shown in bold letters, and amino acids representing $\mathrm{N}$ - and O-glycosylation are circle and boxed respectively. The putative polyadenylation signal (AATAAA) is indicated in italics. The peptide sequences obtained by mass spectrometry analyses are boxed with dotted line. 
1 tatgtggagaatgacgacgcttcttcacttgactgctctgcttgttctgattccattatgt

\begin{tabular}{lllllllllllllllllllll}
1 & $M$ & $W$ & $R$ & $M$ & $T$ & $T$ & $L$ & $L$ & $H$ & $L$ & $T$ & $A$ & $L$ & $L$ & $V$ & $L$ & $I$ & $P$ & $L$ & $C$ \\
\hline
\end{tabular}

62 cattgtgcctccatgcacaggcatgaccattatatggacatggatcaaacctaccgtgat

$\begin{array}{lllllllllllllllllllll}21 & H & \text { C } & \text { A } & \text { S } & M & \text { H } & \text { R } & \text { H } & \text { D } & H & \text { Y } & M & \text { D } & M & D & Q & T & Y & R & D\end{array}$

P21 çatggggaactgtcattattcagggggaagtagctgtgacgccgggtttagctacaat

181 agggaacaaatgaggaacaatgccacgggccgtatgactggcacactatatctagttgc

$\begin{array}{lllllllllllllllllllll}61 & R & E & Q & N & E & E & Q & C & H & G & P & Y & D & W & H & T & I & S & S & C\end{array}$

241 tttaaggcatgtggaagtaaagagagacaatcaccaatcaacatttggtcacatagagcc

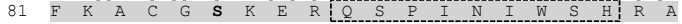

301 ctttccgaaactgccaagactgaaattcaagccacatatgaatcattggatacgaaa

$\begin{array}{llllllllllllllllllllll}101 & \text { L } & F & R & K & \text { L } & \text { P } & \text { R } & \text { L } & K & \text { F } & \text { K } & \text { P } & \text { H } & \text { M } & \text { K } & \text { S } & \text { L } & \text { D } & \text { T } & \text { K }\end{array}$

361 gtgtcaaatcaccaaatcatgcccctgaattcgattctgaggacgaaaacttcatgtt

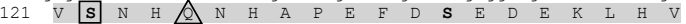

421 aaactgaagaaacttgttgatggacattataaattccgcaatctcccatattcacattgg,

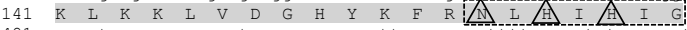

481 aaaagtagacgaaagggctccgaacacagcgttgacagacattt tacacctatggaggct 161 L

541 catttagtgttccatcatgatgagaaaaggaaatcaaacctcctaggattccgttagga 181 A L V F 601 agaaattcagtggtattaatgaatttgttgtcgttggggttttctagaggatggtgat

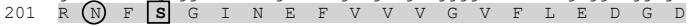
661 gaaggatacggtgatgaaccggacgactatgaatgtaagcgcatattaaagggtcattac $\begin{array}{lllllllllllllllllllll}221 & E & G & Y & G & D & E & P & D & D & Y & E & C & K & R & I & L & K & G & H & Y\end{array}$ 721 gatcattgcgacaacaatggagacaacggttacaactgtgataacggcaacaatgaaac $\begin{array}{llllllllllllllllllllllll}241 & D & H & C & D & N & N & G & D & N & G & Y & N & C & D & N & G & N & N & E & N\end{array}$ 781 aacggaaacaatggtaatggtaacaacggctataacggtaacaacggttataacggtaat $\begin{array}{llllllllllllllllllllll}261 & N & G & N & N & G & N & G & N & N & G & Y & N & G & N & N & G & Y & N & G & N\end{array}$ 841 aacggtgacaatggcaacagtggaaacaatggtaatggtaacaacggttataacggtgac

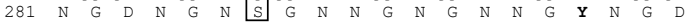
901 aatggcaacagcggaaacaatggtaatggtaacaacggtaataacggtaataacggtggc

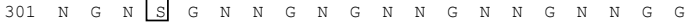
961 aacggaaacaacagaaacaatggtaatggtaacaacggttataacggtaataacggtgat $\begin{array}{lllllllllllllllllllll}321 & N & G & N & N & R & N & N & G & N & G & N & N & G & Y & N & G & N & N & G & D\end{array}$

1021 aatggcaacaacggaaacaatggtaatggtaacaacggaaataatggtaatggtaacaac

$\begin{array}{lllllllllllllllllllll}341 & N & G & N & N & G & N & N & G & N & G & N & N & G & N & N & G & N & G & N & N\end{array}$

1081 ggaaataacggtggcaatggcaacaacggaaacaatggtaatggtaacaacggaataat

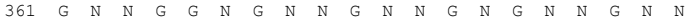

1141 ggtaatggtaacaacgggaataacggtggcaatggcaacaatggtaatggtaacaatgga $\begin{array}{llllllllllllllllllllll} & 381 & G & N & G & N & N & G & N & N & G & G & N & G & N & N & G & N & G & N & N & G\end{array}$

1201 agtaatggtaacggtgactacggtagtaatggtaacaatggtggaaacgggaacaatggt

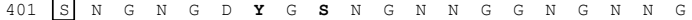

1261 aataacggtgataacggtaatggcgacaatggttataacggtgataatggtaacagtgac

$\begin{array}{lllllllllllllllllllll}421 & N & N & G & D & N & G & N & G & D & N & G & Y & N & G & D & N & G & N & S & D\end{array}$

1321 gggcgactcagacgttgggacttggaaaatgtccgccgcattcataccgagcgatatcac

441 G R $\quad$ L $R$ R

1381 atcagcggaagatgtattgtcaaaaagcaaacgcctcagcaggattctcgaatgcgca

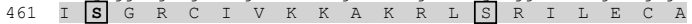

1441 tatagacacaaaaagtcagagaattcaaaggaatggagaacacaaaagtcttgatgtt

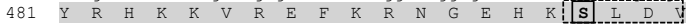

1501 gaaattacaccggaaatggttctaccgccaataaatacagacaatactatacctatgaa 501 E I T

1561 gqatcttofacacccctccttgcacagagagcgtccgttgggttgtagaaaaatgccac

521 Peerf G view S P P T T

1621 gtgcaagtatccagaagggtgcttgatgcattgcggaaggtcgaaggatatgatgatggt

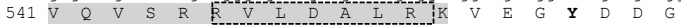

1681 accacgtttgagcaagtatggaaacaagacgtcccacacagagaaacataaacctgtac

$\begin{array}{llllllllllllllllll}561 & T & T & F & E & Q & V & W & K & Q & D & V & P & H & R & E & T & -\end{array}$

1741 ctgtgtacaaaactttatatgaga 


\section{Figure 2 (on next page)}

Amino acid sequence alignment of $\mathrm{N} 66$ and related shell matrix proteins.

Accession numbers: P. mazatlanica N66 (this study, GenBank: MH473230), P. maxima N66 (GenBank: BAA90540.1), P. fucata Nacrein (GenBank: BAA119401.1), P. margaritifera nacrein B2 (GenBank: ADY69618.1), B3 (GenBank: AEC03971.1), B4 (GenBank: AEC03972.1) and C5 (GenBank: AEC03973.1), and P. maxima N45 (GenBank: ACT55367.1). Signal peptide is underlined; conserved carbonic anhydrase domains are highlighted by shaded boxes. Triangles indicate amino acid residues involved in catalysis, open triangles indicates zinc binding histidines. Alpha helix (cylinders) and beta sheets (arrows) are shown along the amino acid sequence. Below the protein sequences is a key denoting conserved sequence $(*)$, conservative (:) and semi-conservative (.) modifications. 
N66 P. mazatianica

N65 P.maxima

Na5 P.maxima

NacreinB 4

NacreinB 3

Nacreins2

Nacreinct

N66 P.mazatlanica

N66 P.maxima

\section{Peert}

Nacreinb3

Nacreinc5

N66 P.mazatianica

N66 P.maxima

N45 P.maxima

NacreinBs

NacreinB 3

Nacreins2

Nacreincs

N66 P.mazatianica N66-P.maxima N45 P. maxima

NacreinBA

NacreinB 3

NacreinB2

Nacreinc5

N66 P.mazatianica

N66 P.maxima

N45 $5^{-}$P.maxima

Nacreinbe

NacreinB 3

NacreinB2

Nacreincs

N66 P.mazatlanica

N66-P.maxima

N45 P. maxima

NacreinB4

NacreinB3

NacreinB2

Nacreincs

N66 P.mazatianica

N66 P.maxima

N45 P.maxima

NacreinBe

NacreinB3

NacreinB2

Nacreinc5

N66_P.mazatianica N66-P.maxima

N45 P.maxima

NacreinBA

NacreinB3

NacreinB2

Nacreincs

N66 P.mazatianica

N66 P.maxima

N45 P.maxima

Nacreinge

NacreinB 3

Nacreini2

Nacreinc5

N66_P.mazatianica

N66- P.maxima

N45 P.maxima

NacreinBA

NacreinB3

NacreinB2

Nacreincs

N66 Peerjacuewing PDF

N66 Peerfreview

N66_P. maxima

Nacreinbs

NacreinB3

NacreinB2

Nacreinc5
MWRMTTLLHLTALLVLI LCHCASMHRHDHYMDMDOTYRDRWGNCIU

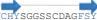

UGLGYCEPSGESSCKAGFSYN

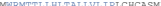

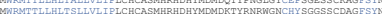
MWRMTTLIHLTSLLVLI PLCHCASMHRHDHYMDMDK TYRNRWGNCHS-GGNSCDAGFSY MWRMTTLIHLTSULVLI PLCHCASMHRHDHYMDMDKTYRNENGNCHYSGGSSCDAGESY

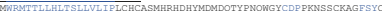

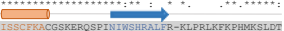
REQNEEQCHGPYDWHT I SSCEKACGSKERQSP I MIVSHRAT,FR-KLPRLKFKPHMKSLDT RD----ICQGPYHWHTI S SCYKACGHKRRQSP INI WSHKAV FLPY LPRL KFKPHMKS LDT RD--- ICQGPYHWHT I SSCYKACGHKRRQSP INIMGHKAVWLPYLPRLKEKPUMKSTD

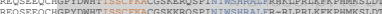

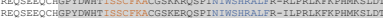
REQSEEQCHGPY DWHT ISSCFKACGSKERQSP INI WSHRAIFR - I LPRLKFKPHMKSLDT
R---DICQGPYYHTI ISCEKACASKKRQSP INIWSHRAVPVPDLPRLKFKPHMKSLDT R----DICQGPYYWHT I SSCEKACASKKRQSP INIWSHRAVPVPDIPRLKFKPHMKSIDT

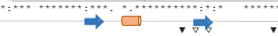

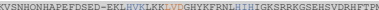

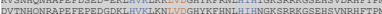
DVTNHONRAPE FEPEDGDKLIVKLIKNLVDGHYKFHNLHI HNGKSRRKGSEHSVNRHF'TPM DVTNHONRA PEFEPEDGDKLHVKLKNL VDGHYKFHNLH I HNGKSRRKGSEHSVNRHFTPM KVSNHONHAPEFDSED - EKLLHKLKNL,VDGHYKFRNLH I H I GKSRRKGSEHSVDRHFTP KVSNHONHAPEFDSED-EKLHVKLKNLVDGHYKFRNLHI I IGKSRRKGSEHSVDRHFTPM

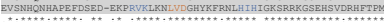
व

EAHLVFHHDEKKEIKPPRI PLGRNFSGINEVVVVGVFLEDGDEGYGDEPDDYECKRILKC EAHLVFHHDDKKE I KPPRVKLGGVYAGRNKEVVVGVFLEVGDEGYGDE PDDDECKR I LKG EAMLVFHHDDKKEI KP PRVKLGGVYAGRNKEVVVGVELEVGDEGYGDEPDDDECKR I LKG EAHLVFRHDEKKEI KPSR I WLGRNESG INE EVVVGVELEVGDEGYGDEPDDDECKR I LKG EAHLVFRHDEKKETRPPRILLGRNFSGINE FVVVGVFLEVGDEGYGDEPDDDECKR I LKG EAHLMFRPDEKKEIKPSR IWLGKNYNGSNEFVVVGVELEVGDEGYGDEPDDDECKR I LKG EAHLVFRHDEKKEIEPPR IWLGRNFNGSNE FVVVGVFLEVGDEGYGDEPDDDECKRILKG

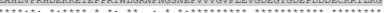

HYDHCDNNGDNGYNCDNGNNENNGNNGN_.........-GNNGYNGNNGYNGNNGDN

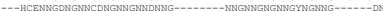
-.- HCENNGDNGNMCDNG _._. HYDHCDNNGDNGYNCDNGNNENNGNNGNGNNGYNGNNGDNGNGNNGYNGNNGYNGNNGDN HYDHCDNNGDNGYNCDNGNNGNNGNNGN_........-GNNGYNGNNGYNGNNGDN HYDHCDNNGDNGYNCDNGNNGNNGNNGNGNNDYNGNN -

GNSGNNGNGNNGYNG_......... DNGNSGMNGNGNNGNNGNNGGN

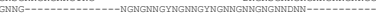

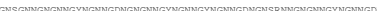
GNSGNNGN-1... GNNGYNGNNGYNGNNGDNGNGGNMGNGNGYNGNNGGN GNSGNNGN-1..-GNNGYNGNNGYNGNNGDNGNSGNNGNGNNGYNGNNGGN

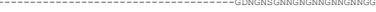

GNNRNNGNGNNGYNGNNGDNGNNGNNGNGNNGNNGNGNNG-_-_-_-NNGG -......

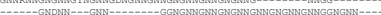

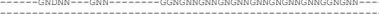

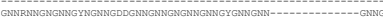
GNNRNNGNGNNGYNGNNGDNGNNGNNGNGNNGNNGNGNNGNNGNGNNGNNGGNDNNGNNG GNNRNNGNGNNGYNGNNGDNGNNGNNGNGNNGNNG_...-.-NGNNGNNGDNGNNGNNG

NGNNGNNGNGNNGNNGNGNNGNNGGNGNNGNGNNGSNGNGDYGSNGNNGGNGNNGNNGDN

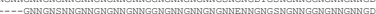
_

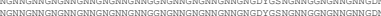
NGNNGNNGNGNNGNNGNGNNGNNGGNGNNGNGNNGNNGNGDYGSNGNNGGNGNNGNNGDN NGNNGNNGNGNNGNNGNGNNGNNGGNGNNGNGNNGNNGNGDYGSNDNNGGNGNNGNNGDN

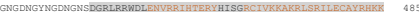
GNGDNGYNGDNGNSDGRLRRWDLAWVRRMHARYHFSGGCIVKKGRRISRTLECAYRHEK 467 -NGDNGYNGDNGNSDGRLRRWD LANVRRMIIABRYHESGGCIVRKAKRLSRTL PCAYRHKR - 310 GNGDNGYNGDNGNSDGR PRRWDLENVRRMHTERYHESGRCIVKKAKRISRTLECKYRHKM $\quad 525$ GNGDNGYNGDNGNSDWRLRRWDLENARRMITERYHESRRCIVKKAKRLSRTLECAYBHKM 509 GNGDNGYNGDNGNSDGRLRRWDLENYRRMHTR PYHFSGRCTYKRKAKRLSRT DCAYRHKR 470 GNGDNGYNGDNGNSDGRLSRWDLENVRRIHTERYHF SGRDIVKIKARRISRILDCAYRHEK 354

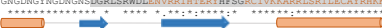
WPEFKRNGEHKSLDVEITPEMVLPP IKYRQYYTYEGSLTTPPCTESWRWWERCHVOVS WREEXRNGGEEKGLDVDITPEMVLP PMKYRHYYTYEGSLTTPFCNETVLWVVEKCHVOVS VREERRNGEEKGLDVDITPEMVLP PMKYRHYYTYEGSLSTPPCNETVLWVVENATCKYP WPE PKR NGEHKSEDVE ITPEMVLPP IKYROYYTYBGSLTTPPCNETVIWYVEKCHWOVS UREFKRNGEHKGLDVE ITPEMVLPP IKYROYYTYZGSLTTPPCDETVLWVVEKCHWOVS WREFWWISEHKSLDVEITPEMVLP P INYROYYTYEGSLTTPPCNETVLWVVEKCHVOVS VREFKRIGEHKSLDVEITPEMVLPPTKYROYYTYEGSLTTPPCTESVLWVVEKCHVOVS:

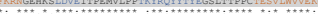

\section{5

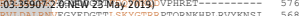

GCLMRCGT SKDM---KMVPR-....... 38 ?

RVIDALIRKVEGYDDGTTLSKEGTRRPTQRNIKPVPVYKNEI $\quad 626$

RULDALRXVEGYDDGTTLSKEGTRRPTQRNIKPVTVYKNEI 610

RVI DIALPKVEGYDDGTTLSKEGTRPPTORNIEPVPVYKNEI 571

RVIDATRSVEGYDDGTTLSKEGTRRPTORNIKEVTVYKNFI 455 
Figure 3 (on next page)

Biochemical characterization of the native and recombinant N66 from P. mazatlanica.

Analysis by $10 \%$ SDS-PAGE. A) Acetic soluble matrix protein extract; B) CBB: Coomassie Brilliant Blue; Silver nitrate stain; and PAS: Periodic acid/Schiff staining. MM: molecular marker; N: Native protein, R: Recombinant protein and Ovoalbumin as positive control (+) for PAS. 
A) Peer.B)

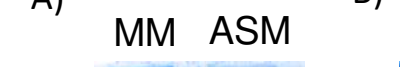

CBB

PAS

200-

$116-$

97-

66-

200-

$116-$

97-

66-

45-

45-

31-

21.5-

31-

$R$

N R

$\mathrm{N}(+)$ 


\section{Figure 4 (on next page)}

Carbonic anhydrase activity of native and recombinant N66 from P. mazatlanica.

Carbonic anhydrase activity was visualized by soaking the agarose plate in bromocresol purple, and exposing the plate to saturated $\mathrm{CO}_{2}$ water. Commercial bovine carbonic anhydrase was used as positive control and water as negative control. N: native N66 and R: Recombinant N66 from P. mazatlanica. 


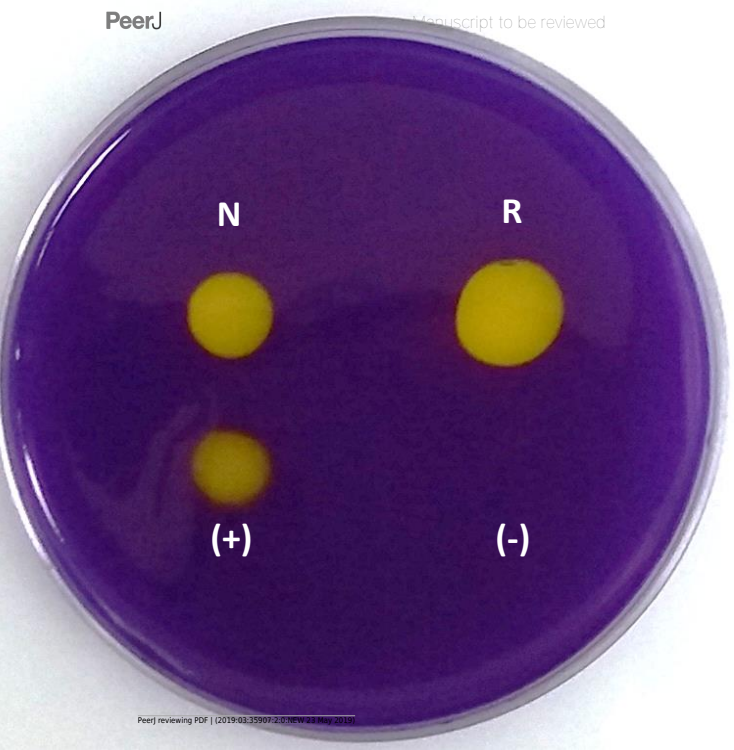


Figure $\mathbf{5}$ (on next page)

Effect of native and recombinant $\mathrm{N} 66$ from P. mazatlanica on $\mathrm{CaCO}_{3}$ crystal growth.

Effect of native and recombinant $\mathrm{N} 66$ from P. mazatlanica on $\mathrm{CaCO}_{3}$ crystal growth. SEM micrographs of calcium carbonate crystal growth in the presence of $0.2 \mathrm{mg} / \mathrm{mL}$ of $\mathrm{N} 66$ (native or recombinant) incubated at $4{ }^{\circ} \mathrm{C}$ for 21 days. Controls (A-C): Salts without N66; Native N66 (D-F): Salts in the presence of native N66 and, Recombinant (G-I): Salts in the presence of recombinant N66. Pictures are representative of three independent experiments. 


\section{Table 1 (on next page)}

Primer sequences and expected amplicon size for N66 amplification. 
1

\begin{tabular}{llc}
\hline \multicolumn{1}{c}{ Primers } & \multicolumn{1}{c}{ Primer sequence (5'-3') } & $\begin{array}{c}\text { Amplicon } \\
\text { size (pb) }\end{array}$ \\
\hline N66_1F & ATGTGGAGAATGACGACGCTT & 425 \\
N66_425R & TGTGAATATGGAGATTGCGG & \\
\hline N66_1F & ATGTGGAGAATGACGACGCTT & 680 \\
N66_680R & CCTTTAATATGCGCTTACATTC & 962 \\
\hline N66_680Fw & GAATGTAAGCGCATATTAAAGG & 1766 \\
N66_1642Rv & GGGACGTCTGGTTCCATAC & \\
\hline N66_1F & ATGTGGAGAATGACGACGCTT & 1642 \\
N66_1766R & CTCATATAAAGTTTTTGTACACAGG & \\
\hline N66_HindF & GTGAAGCTTTGCCTCCATGCACAGGCATG & \\
N66_HindR & CACAAGCTTGGGACGTCTTGTTTCCATAC & \\
\hline
\end{tabular}

2 
Table 2 (on next page)

Amino acid composition of $\mathrm{N} 66$ from mantle of $P$. mazatlanica. 
1

\begin{tabular}{ccc}
\hline $\begin{array}{c}\text { Amino acid } \\
\text { residue }\end{array}$ & Residues & Mol\% \\
\hline Ala & 10 & $1.7 \%$ \\
Arg & 35 & $6.1 \%$ \\
Asn & 113 & $9.6 \%$ \\
Asp & 35 & $6.1 \%$ \\
Cys & 14 & $2.4 \%$ \\
Gln & 9 & $1.6 \%$ \\
Glu & 30 & $5.2 \%$ \\
Gly & 91 & $5.8 \%$ \\
His & 29 & $5.0 \%$ \\
Ile & 6 & $2.8 \%$ \\
Leu & 28 & $4.9 \%$ \\
Lys & 30 & $5.2 \%$ \\
Met & 8 & $1.4 \%$ \\
Phe & 13 & $2.3 \%$ \\
Pro & 17 & $3.0 \%$ \\
Ser & 28 & $4.9 \%$ \\
Thr & 16 & $2.8 \%$ \\
Trp & 7 & $1.2 \%$ \\
Tyr & 23 & $4.0 \%$ \\
Val & 24 & $4.2 \%$ \\
Mr & 63.68 & \\
pI & 7.38 & \\
\hline
\end{tabular}

2 


\section{Table 3(on next page)}

Summary of the native N66 purification from the shell of $P$. mazatlanica. 
1

\begin{tabular}{lcccccc}
\hline \multicolumn{1}{c}{ Step } & $\begin{array}{c}\text { Protein } \\
(\mathbf{m g} / \mathbf{m l})\end{array}$ & $\begin{array}{c}\text { Total } \\
\text { protein } \\
(\mathbf{m g})\end{array}$ & $\begin{array}{c}\text { Total } \\
\text { activity } \\
(\mathbf{U})\end{array}$ & $\begin{array}{c}\text { Specific } \\
\text { activity } \\
(\mathbf{U} / \mathbf{m g})\end{array}$ & $\begin{array}{c}\text { Purification } \\
(\mathbf{f o l d})\end{array}$ & $\begin{array}{c}\text { Yield } \\
(\%)\end{array}$ \\
\hline $\begin{array}{l}\text { Acetic acid } \\
\text { extraction-dialysis }\end{array}$ & 19.20 & 19.20 & 990.72 & 51.60 & 1 & 100 \\
Sepharose-Ni & 0.32 & 3.20 & 560.00 & 175.0 & 3.39 & 56.52 \\
\hline
\end{tabular}

2 Protein concentration was estimated by Lowry method. The experiments were conducted three

3 times. CA activity was estimated by Wilbur and Anderson method.

4 


\section{Table 4 (on next page)}

Native N66 peptide sequences matching with mass spectrometry and deduced amino acid sequences from the N66 gene.

*Peptides obtained only for the 60 kDa band. 
1

\begin{tabular}{lcc}
\hline Peptide & Calculated mass $(\mathrm{Da})$ & Observed mass $(\mathrm{Da})$ \\
\hline QSPINIWSHR & 1237.38 & 1237.64 \\
NLHIHIGK & 931.11 & 931.54 \\
HFTPMEAHLVFHH & 1465.69 & 1500.73 \\
RWDLENVR & 1087.20 & 1087.56 \\
SLDVEITPEMVLPPIK* & 1781.14 & 1780.97 \\
RVLDALR* $^{*}$ & 842.01 & 842.52 \\
\hline
\end{tabular}

2 